\title{
Physiological and molecular genetic studies for cotton leaf worm (Spodoptera littoralis) tolerance on six Egyptian soybean cultivars
}

\author{
Naglaa A. Ashry ${ }^{1}$, Marwa M. Ghonaim ${ }^{1}$, Heba I. Mohamed ${ }^{2}$, Asmaa M. Mogazy ${ }^{2}$ \\ 1 Field Crops Research Inst., Agricultural Research Center, Giza, Egypt \\ 2 Faculty of Education, Biological and Geological Sciences Department, \\ Ain Shams University, Cairo, Egypt \\ Corresponding author: marwa_ghonaim2006@yahoo.com
}

\begin{abstract}
Cotton leaf worm (Spodoptera littoralis) is considered one of the most destructive agricultural pests. Six soybean cultivars (Giza-21, Giza-22, Giza-35, Giza-82, Giza-83 and Giza-111) were grown under natural infection with cotton leaf worm. The effect of two elicitors, methyl jasmonate and sodium nitroprusside on enhancing the ability of susceptible cultivars to tolerate (Spodoptera littoralis) was studied. Giza-35 and Giza-111 showed tolerance performance under natural infection compared to Giza 22 and Giza 82 as sensitive ones, while Giza 83 and 21 showed moderate tolerance. Both treatments positively affected seed yield and its components and fatty acid composition. Extracted fatty acids showed great changes in treated plants comparing with the untreated controls. Plants treated with the two elicitors showed an increase in Linoleic acid and Linolenic acid fatty acids and decrease in Palmitic acid and Palmitolic acid content. Treatment with methyl jasmonate was found to be more effective than sodium nitroprusside and enhanced resistance of the susceptible cultivars. Eight IRAP and iPBS retrotransposon-based markers were used to detect genetic differences among studied soybean cultivars and to develop molecular genetic markers for cotton leaf worm infestation. The technique successfully identified soybean genotypes in addition to nineteen molecular markers related to soybean tolerance.
\end{abstract}

Key words: Soybean, Methyl jasmonate, Sodium nitroprusside, Fatty acids, IRAP-iPBS.

\section{Introduction}

Soybean crop (Glycine max L) is a very important economic crop belongs to leguminosae, it is attacked by cotton leaf worm (Spodoptera littoralis) which considered the major pest throught out its growing season (Massouda et al., 2014). Soybean crop is accounting for $58 \%$ of the world oil-seed production; it is the largest oil seed crop worldwide in terms of production and consumption (SoyStats, 2011). Soybean is a significant source of fatty acids, proteins, vitamins, minerals, amino acids and other nutrients for both humans and animals, it has other industrial importance as feedstocks and combustible fuels (Maltas et al., 2011). In Egypt, soybean production in 2016 was 35000 ton (http://www.fao.org/faostat/en/\#data/QC).

Cotton leaf worm (Spodoptera littoralis) is considered one of the most destructive agricultural lepidopterous pests. It can attack numerous economically important crops all over the year (Abouelghar et al., 2013). Chemical pesticides were effectively used against insect pests but are associated with a number of drawbacks including high costs and concerns about environmental pollution and food safety, for these reasons, plants can be treated with elicitors to induce resistance to herbivores (Mohamed and Abd-El Hameed, 2014). Several environmental manipulations can be attained by employing chemical insecticides but still the developing of tolerant cultivars is the best choice.

Jasmonic acid (JA) and its methyl ester (MeJa) are cyclopentanone compounds which act as signal transduction molecule in plant defense reactions, induces secondary metabolites and is an important phytohormone that is involved in signaling wound responses (Howe, 2004 and Deng, 2005). Because of the wide natural distribution of JA and their effects on many physiological processes in plants they have been proposed as naturally occurring plant growth regulators (Mohamed and Latif 2017). Nitric oxide (NO) is a small, highly diffusible, gaseous free-radical and a ubiquitous bioactive molecule (Lamattina et al., 2003). Nitric oxide at the lower concentration can serve as a signal in plant developmental, hormonal and stress responses (Akladious and Mohamed 2017). NO donor molecules, such as sodium nitroprusside produces nitric oxide which is a lipophilic gas that is favorable because of its relatively low cost (Filippou et al., 2013) and plays an important role in regulating the response of numerous plants to a variety of stressors and stimulate plant defense responses (Garcia-Mata and Lamattina, 2007 and Klessig et al., 2000).

Molecular marker assay is playing a vital role in plant biology and in molecular breeding, different DNA-based marker technologies have been developed to indicate polymorphism by assaying subsets of the total amount of DNA in a genome. DNA fingerprinting is useful for identification, determination of family relationship, linkage mapping, phylogenetics, systematics, conservation, molecular ecology, localization of disease loci and determination of genetic variation, (Golenberg $\boldsymbol{e t}$ al., 1990). Variation in genome size is often attributed to repetitive DNA (Flavell $\boldsymbol{e t} \boldsymbol{a l}$., 1974). Transposable elements constitute a major portion of the repetitive 
DNA of plant genomes, contributing significantly to genome size variation (Vicient $\boldsymbol{e t}$ al., 1999). Soybean genome contains up to 40 to $60 \%$ repetitive DNA (Gurley et al., 1979). Plants have high transposon percentages in proportion with their genome size; Arabidopsis thaliana contains $14 \%$ transposon sequence (genome size equals $125 \mathrm{Mb}$ ), while $80 \%$ of Hordeum vulgare genome contains TEs (genome size equals $5300 \mathrm{Mb}$ ), Glycine $\max$ contains 76\% TEs sequences out of its 1,115 Mbp genome (Gozukirmizi et al., 2015). Retrotransposons are mobile genetic elements which transpose replicatively through RNA intermediates. They are found in all major eukaryote divisions and comprise major fractions of the genomes of plants (SanMiguel et al., 1996; Pearce et al., 1996). In both monocot and dicot angiosperms, LTR retrotransposons comprise highly heterogeneous populations, whose members frequently span different genera (Voytas et al., 1992). Retrotransposons based markers are used in a variety of applications, including DNA fingerprinting, measurement of genetic diversity, phylogenetic relationship studies, genetic mapping, genes analyses, genome evolution, population structure, and cladistic relationships have been applied successfully in some plant genera and species (Zein et al., 2010). Retrotransposons are also an ideal target for developing molecular marker techniques because of their amplification mechanism and sequence characteristics. There are different types of transposon based marker techniques. Some of them are; Inter-Retrotransposon Amplified Polymorphism (IRAP) and Inter Primer binding sits (iPBS) (Gozukirmizi et al., 2015).

This work is aimed to study the effectiveness of two elicitors, methyl jasmonate and sodium nitroprusside, for controlling cotton leaf worm infestation under field condition to test their effects on yield and seed fatty acid composition and to use retrotransposon-based marker techniques (IRAP and iPBS) to detect molecular markers for cotton leaf worm tolerance in soybean.

\section{Materials and Methods}

A field experiment was conducted in the Agricultural Research Centre (ARC) experimental farm, Giza, Egypt during 2014 and 2015 summer seasons. Day temperature ranged from 28 to $45^{\circ} \mathrm{C}$ with an average of $36.7 \pm 3.1^{\circ} \mathrm{C}$ while that at night was 22.3 $\pm 2.2^{\circ} \mathrm{C}$. Daily relative humidity averaged $43.5 \pm$ $4.6 \%$, in a range between 31.1 and $57.3 \%$. Soybean seeds cultivar (Giza-21, Giza-22, Giza-35, Giza-82, Giza-83 and Giza-111) were obtained from (ARC), Giza, Egypt. Soybean seeds were selected for uniformity, the selected seeds were washed with distilled water, sterilized with $1 \%$ sodium hypochlorite solution for about 2 min and thoroughly washed again with distilled water and left to dry at room temperature $\left(25^{\circ} \mathrm{C}\right)$ for about $1 \mathrm{hr}$. Rhizobial inoculants were applied as peat slurry containing $10^{7}$ Rhizobium/g.
Soybean seeds were sown in the field on the $12^{\text {th }}$ June apart in rows $60 \mathrm{~cm}$ and hills were spaced $20 \mathrm{~cm}$. Thinning was done before first irrigation to secure two plants/ hill. The soil had a clay loam texture (sand $20 \%$, silt $25 \%$ and clay $55 \%$ ). Experiment was laid out in randomized complete block design (RCBD) with three replications; plot area was $21 \mathrm{~m}^{2}(4.2 \mathrm{~m} \times 5.0 \mathrm{~m})$. Thirty days after sowing (DAS) the first group was sprayed with MeJa $(20 \mu \mathrm{M})$, the second group was sprayed with SNP $(500 \mu \mathrm{M})$ and the third group was sprayed with distilled water and served as control. The treatment was repeated for three times with 4 days interval. At maturity (120 DAS) ten plants were randomly chosen from each replication and the following parameters were studied; number of pods/ plant, number of seeds/ plant, fresh and dry weight of pods and seed index and biochemical components in yielded seeds (total soluble proteins, total soluble sugars, reducing sugars and fatty acid composition). Leaf defoliation (percentage of the leaf area destroyed by the pests) was measured as an indicator for insect lesion; the accumulative damage caused by the defoliator larvae of each of 10 randomly chosen leaves was recorded, percentage of infestation was calculated according to the formula given by Kasopers 1965 .

\section{Biochemical analysis}

Fresh samples (1g) were grounded in $80 \%$ aqueous ethanol and the mixture was boiled for $10 \mathrm{~min}$ and then centrifuged at $2000 \mathrm{rpm}$ for $10 \mathrm{~min}$. The supernatant was collected and the pellets were re-extracted in $5 \mathrm{ml}$ of $80 \%$ ethanol. The supernatants of both extractions were combined and completed to $50 \mathrm{ml}$ by measuring flask with ethanol 80\% (A.O.A.C 1984).

\section{Determination of total soluble protein}

Seeds of soybean plants $(0.5 \mathrm{~g}$ fresh seeds) was grounded in $5 \mathrm{ml}$ phosphate buffer $\mathrm{pH} 6.5$ and then centrifuged at $6000 \mathrm{~g}$ for 10 minutes. The supernatant is the protein extract. The residue was washed with 2 $\mathrm{ml}$ of distilled water. The supernatant and the washing were combined to give the total soluble proteins. The total soluble proteins content was measured by using Folin- Cicalteu reagent according to Lowry et al., (1951) and modified by Hartree (1972).

\section{Determination of carbohydrate fractions}

Seeds of soybean plants $(1 \mathrm{~g})$ were grounded in $80 \%$ aqueous ethanol and the mixture was boiled for $10 \mathrm{~min}$ and then centrifuged at $2000 \mathrm{~g}$ for $10 \mathrm{~min}$. The supernatant was collected and the pellets were reextracted in $5 \mathrm{ml}$ of $80 \%$ ethanol. The supernatants of both extractions were combined and completed to 50 $\mathrm{ml}$ by measuring flask with ethanol $80 \%$ (A.O.A.C 1984).

Total soluble sugars were determined in ethanolic extract using the phenol sulphuric method according to Dubois et al., (1956) and modified by Dey (1990). Reducing sugars were determined in the ethanolic extract using dinitrosalicylic acid method according to 
Miller (1959). Non reducing sugars were calculated by difference between the total soluble sugars and reducing sugars. Starch was estimated according to (Rose et al., 1991) by perchloric acid method.

\section{Determination of fatty acids}

Lipids were extracted according to Kates and Eberhardt (1957). The methyl esters of fatty acids were prepared according to the method of Glass (1971). The methylated samples were subjected to analysis by GLC Agilent technologies $6890 \mathrm{~N}$ Network GC system Oven. FAME condition was: Initial temp. $50{ }^{\circ} \mathrm{C}$, Initial time $2 \mathrm{~min}$. Inlet temp.: $250{ }^{\circ} \mathrm{C}$. Detector temp.: $280^{\circ} \mathrm{C}$, Flame Ionization Detector (FID), Flow: $1.5 \mathrm{ml} / \mathrm{min}$. Column: HP-5 (5\% phenyl methyl siloxane) $\mathrm{L}=30 \mathrm{~m}, \mathrm{D}=320 \mu \mathrm{m}$. Flame thickness $=0.25 \mu \mathrm{m}$. Carrier gas: $\quad \mathrm{N}_{2} 30 \mathrm{ml} / \mathrm{min}, \mathrm{H}_{2}$ $30 \mathrm{ml} / \mathrm{min}$ and Air $30 \mathrm{ml} / \mathrm{min}$.

\section{Retrotransposon-based markers}

Genetic diversity among the studied cultivars was carried out using inter-retrotransposon amplified polymorphism (IRAP) and inters primer binding site (iPBS) marker systems (Fig. 2). Eight IRAP and iPBS primers were applied on six soybean cultivars. The codes and sequences of the tested primers are listed in Table (1). Genomic DNA isolation and quantification from young leaves of six soybean genotypes was performed according to the method advised by http\lwww.primerdigital.com/DNA. PCR reactions were conducted as follows: $95^{\circ} \mathrm{C}$ for 3 min hot start; 35 cycles $\left(95^{\circ} \mathrm{C}\right.$ for $20 \mathrm{sec}$, Annealing temperature (according to each tested primer as listed in Table (1) for $30 \mathrm{sec}$ and $72^{\circ} \mathrm{C}$ for $90 \mathrm{sec}$ ); final extension at $72^{\circ} \mathrm{C}$ for $5 \mathrm{~min}$. Electrophoresis was performed on $1.2 \%$ agarose gel in 1xTHE buffer at constant voltage of 70 Volts for 14 hours. Electrophoresis Gene Ruler ${ }^{\mathrm{TM}}$ DNA ladder mix (Thermo scientific) 100-10,000 base range was diluted with $1 \mathrm{x}$ gel loading buffer to final concentration $25 \mathrm{ng} / \mu \mathrm{l}$ and were used as ladder DNA. Gels were visualized by Alpha Innotech Gel Imager 2000 Multimage Light Cabinet AlphaImager Gel Documentaion.

Table 1. List of the tested primers used for DNA profiling of soybean genotype.

\begin{tabular}{llll}
\hline Primers & Sequences & Tm C & G:C \\
\hline iPBS-2219 & '5 gaacttatgccgatacca'3 & 51.5 & 44.4 \\
\hline iPBS-2394 & '5 gagcctaggcca'3 & 48.5 & 66,7 \\
\hline iPBS-2399 & '5 aaactggcaacggcgcca'3 & 63.4 & 61.1 \\
\hline IRAP-4341 & '5 gtcccacagcttgggcaacag'3 & 63.7 & 61.9 \\
\hline IRAP-4361 & '5 gtcgaccttcccggcatgaa'3 & 61.4 & 60 \\
\hline IRAP-4364 & '5 atagcgccgagatgcatgct'3 & 59.4 & 55 \\
\hline & & & \\
\hline IRAP-4368 & '5 gatgttgcggtggatgtgtggtaagact'3 & 66.6 & 50 \\
\hline IRAP-4377 & '5 cgtaccctttaagggatcaaaacc'3 & 61.3 & 44 \\
\hline
\end{tabular}

\section{Statistical Analysis}

All data collected were subjected to analysis of variance according to Gomez and Gomez (1984), treatment means were compared using Duncan's Multiple Range Test (Duncan 1955) using MSTAT-C computer software package 1990. Data scoring for IRAP and iPBS fragments were treated as binary characters for similarity matrix development, cluster analysis was performed using NTSYs-pc version 2.11 software as described by Rohlf (1993).

\section{Results and Discussion}

\section{Effect of MeJa and SNP on percentage of soybean defoliation}

Percentages of soybean leaf area injured by cotton leaf worm (defoliation) are illustrated in Fig. (1). Giza-82 and Giza-22 proved to be the most susceptible genotypes for cotton leaf worm infestation; the percentage of defoliation was (34 and 28\%). while, Giza-83 and Giza-21 showed moderate resistant, on the other hand, Giza-35 and Giza-111 were detected the lowest estimates and proved to be more resistant (18 and $13 \%$ respect.). It was found that treatment of soybean plants with MeJa or SNP enhanced resistance in susceptible genotypes and decreased mean percentage of defoliation comparing with untreated plants. In general, methyl jasmonate (MeJa) treatment achieved better results than SNP treatment. Results are obtained in agreement with Zayed (2007) who reported that Giza-111 is considered to be resistant genotype for cotton leaf worm based on consumed leaf area recorded comparing with Giza-82 and Giza-22 which are susceptible genotypes. It was also found that treatment of soybean plants with $\mathrm{MeJa}$ and/or SNP enhanced the resistance in susceptible genotypes as it decreased defoliation percentage comparing with untreated plants. These results are in conformity with the findings of Thaler et al. (2001) who found that the application of jasmonic acid caused reduction in the population of Frankliniell aoccidentalis and aphids in tomato field plots.

\section{Effect of MeJa and SNP on yield and its components}

Data in Table (2) were significant difference among control and treatments for each genotype in number of pods plant except for Giza-21 which 
showed insignificant differences when treated with NSP while treating the same genotype with MeJa resulted in positive significant difference, it is also worthy to mention that no significant differences between the two treatments were observed except for Giza-111 which revealed positive and significant difference when treated with MeJa. Mean number of seeds per plant was increased significantly with both treatments (MeJa and SNP) and showed significant increases as compared with their control. MeJa effect was found to be better than that induced with SNP treatment in all soybean genotypes except Giza-111 (Table 2). There was insignificant difference in fresh weight of pods between all soybean genotypes except the most tolerant genotypes (Giza-35 and Giza-111) which showed significant increase in fresh weight/plant. MeJa treatment induced significant increase in pods fresh weight in all genotypes except Giza-83 when compared to its respective controls. On the other hand, SNP treatment induced significant increase in all genotypes except the two tolerant genotypes Giza-35 and Giza-111. By comparing the effects of the two treatments it was clear that no significant difference observed for mean fresh weight/plant in all soybean genotypes (Table 2).

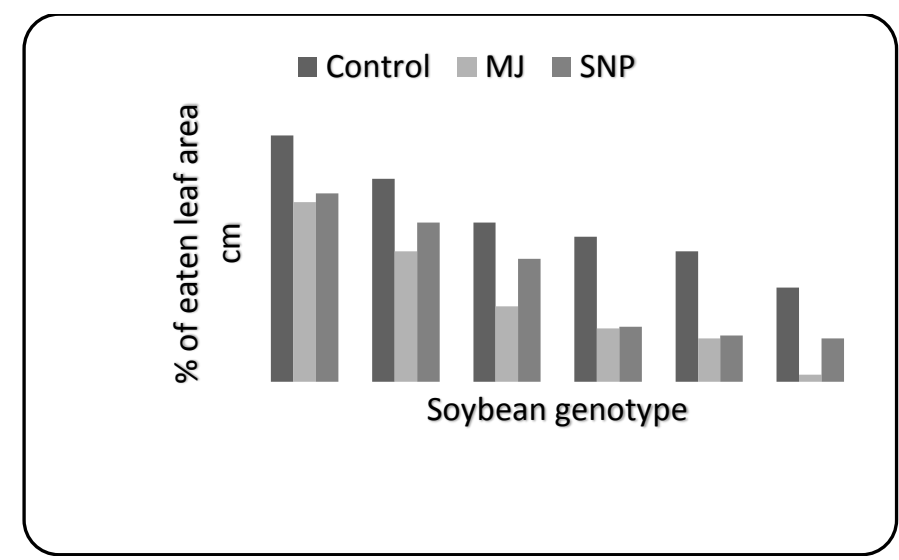

Figure (1) Effect of foliar spray of methyl jasmonate and sodium nitroprusside on soybean defoliation under natural cotton leaf infestation.

Results in table (2) showed insignificant difference in pods dry weight in all soybean genotypes. Both treatments (MeJa and SNP) showed insignificant effect in pods dry weight with an exception in Giza 21, Giza 35 and Giza 111 which induced a significant increase in pod dry weight and again the for mentioned genotypes revealed significant difference as a result of their response to treatments, $\mathrm{MeJa}$ was found to have positive and significant effects on means of seed dry weight/plant. Seed index in soybean cultivars showed significant differences under natural cotton leaf worm infection, the most sensitive genotypes Giza-82 and Giza-22 recorded the lowest seed indices, no significant differences were observed between the two treatments in all cultivars except for Giza- 111 where MeJa had positive and significant effects. Data showed that a significant increase in yield and its components was observed for tolerant genotypes as compared with the susceptible ones under natural infection with cotton leaf worm. These results are in accordance with Myers et al., (2005) who stated that, insect infection can severely reduce soybean growth and yield by reducing the number of pods, number of seeds/pod and individual seed weight. Significant yield loss may be due to the diversion of photosynthesis in response to chewing insect infection Myers et al., (2005).

Effect of MeJa and SNP foliar application on seed chemical components
Seed chemical components of soybean cultivars treated with MeJa and SNP are shown in table (3). From the resulted data it is obvious that there were significant differences among studied genotypes for all traits (total soluble protein, total soluble sugars, reducing sugars and starch content) under natural conditions. Significant and positive differences were observed $(\mathrm{P}>5 \%)$ between MeJa and SNP treatments for total soluble protein compared to its respective control, on the other hand, there were significant differences on the effects of both treatments for all. Generally, treatment with MeJa revealed positive increase in total soluble protein than SNP for all soybean cultivars. Treatment with both MeJa and SNP was found to have positive and significant effects on total soluble sugars for all genotypes compared to its respective control. Comparison between the effects of both treatments was significant $(\mathrm{P}>0.05)$ with slight increase in the effect of MeJa on all cultivars. Regarding seed reducing sugars content, significant differences were obtained when soybean cultivars were sprayed with MeJa compared to its respective control, the same trend was observed for SNP treatment. Differences between both treatments was found to be significant and positive for all genotypes in spite of the fact that treatment with MeJa showed more increase in reducing sugars content than SNP. 
Table 2 . Effect of foliar spray with MeJa and SNP on yield attributes of soybean cultivars under natural infestation with cotton leaf worm.

\begin{tabular}{|c|c|c|c|c|c|c|}
\hline Uूँ & Treatments & $\begin{array}{c}\text { No. of pods/ } \\
\text { plant }\end{array}$ & $\begin{array}{l}\text { No. of seeds/ } \\
\text { plant }\end{array}$ & $\begin{array}{c}\text { F. wt. of pod } \\
(\mathrm{g})\end{array}$ & $\begin{array}{c}\text { D. wt. of pod } \\
(\mathrm{g})\end{array}$ & $\begin{array}{l}\text { Seed index } \\
(\mathrm{g})\end{array}$ \\
\hline \multirow{3}{*}{ 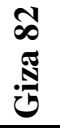 } & Control $\mathrm{H}_{2} \mathrm{O}$ & $22.4 \mathrm{~g}$ & $40.8 \mathrm{p}$ & $0.72 \mathrm{~d}$ & $0.26 \mathrm{c}$ & $9.44 \mathrm{f}$ \\
\hline & MeJa $20 \mu \mathrm{M}$ & $70.8 \mathrm{bc}$ & $125.0 \mathrm{f}$ & $1.09 \mathrm{a}-\mathrm{c}$ & $0.33 \mathrm{c}$ & $15.89 \mathrm{de}$ \\
\hline & SNP $500 \mu \mathrm{M}$ & $55.5 \mathrm{~b}-\mathrm{e}$ & $89.0 \mathrm{k}$ & $1.01 \mathrm{a}-\mathrm{c}$ & $0.30 \mathrm{c}$ & $14.16 \mathrm{de}$ \\
\hline \multirow{3}{*}{ 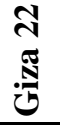 } & Control $\mathrm{H}_{2} \mathrm{O}$ & $23.4 \mathrm{fg}$ & $46.4 \quad \mathrm{o}$ & $0.92 \mathrm{~cd}$ & $0.27 \mathrm{c}$ & $9.56 \mathrm{f}$ \\
\hline & MeJa $20 \mu \mathrm{M}$ & $74.6 \mathrm{~b}$ & $127.3 \mathrm{e}$ & $1.12 \mathrm{a}-\mathrm{c}$ & $0.34 \mathrm{bc}$ & $16.28 \mathrm{a}-\mathrm{d}$ \\
\hline & SNP $500 \mu \mathrm{M}$ & 58.2 b-e & $98.4 \mathrm{j}$ & $1.02 \mathrm{a}-\mathrm{c}$ & $0.30 \mathrm{c}$ & $15.08 \mathrm{c}-\mathrm{e}$ \\
\hline \multirow{3}{*}{ 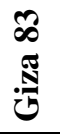 } & Control $\mathrm{H}_{2} \mathrm{O}$ & $25.8 \mathrm{fg}$ & $54.5 \mathrm{n}$ & $0.93 \mathrm{~cd}$ & $0.29 \mathrm{c}$ & $12.67 \mathrm{e}$ \\
\hline & МeJa $20 \mu \mathrm{M}$ & $76.0 \mathrm{~b}$ & $130.3 \mathrm{~d}$ & $1.14 \mathrm{abc}$ & $0.34 \mathrm{bc}$ & $17.76 \mathrm{a}-\mathrm{c}$ \\
\hline & SNP $500 \mu \mathrm{M}$ & $59.2 \mathrm{~b}-\mathrm{d}$ & $116.2 \mathrm{i}$ & $1.03 \mathrm{a}-\mathrm{c}$ & $0.30 \mathrm{c}$ & $15.36 \mathrm{c}-\mathrm{e}$ \\
\hline \multirow{3}{*}{ 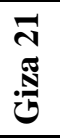 } & Control $\mathrm{H}_{2} \mathrm{O}$ & $33.6 \mathrm{e}-\mathrm{g}$ & $69.2 \mathrm{~m}$ & $0.94 \mathrm{~cd}$ & $0.29 \mathrm{c}$ & $13.28 \mathrm{de}$ \\
\hline & MeJa $20 \mu \mathrm{M}$ & $76.8 \mathrm{ab}$ & $130.2 \mathrm{~d}$ & $1.19 \mathrm{ab}$ & $0.46 \mathrm{ab}$ & $18.60 \mathrm{ab}$ \\
\hline & $\mathrm{SNP} 500 \mu \mathrm{M}$ & $61.0 \mathrm{~b}-\mathrm{d}$ & $119.0 \mathrm{~h}$ & $1.05 \mathrm{a}-\mathrm{c}$ & $0.31 \mathrm{c}$ & $15.64 \mathrm{~b}-\mathrm{e}$ \\
\hline \multirow{3}{*}{ 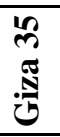 } & Control $\mathrm{H}_{2} \mathrm{O}$ & $38.6 \mathrm{~d}-\mathrm{g}$ & $\begin{array}{ll}74.3 \quad 1 \\
\end{array}$ & $0.97 \mathrm{bc}$ & $0.29 \mathrm{c}$ & $13.88 \mathrm{de}$ \\
\hline & MeJa $20 \mu \mathrm{M}$ & $80.2 \mathrm{ab}$ & $142.7 \mathrm{c}$ & $1.23 \mathrm{a}$ & $0.47 \mathrm{a}$ & $18.64 \mathrm{ab}$ \\
\hline & SNP $500 \mu \mathrm{M}$ & $65.0 \mathrm{bc}$ & $123.3 \mathrm{~g}$ & $1.06 \mathrm{a}-\mathrm{c}$ & $0.32 \mathrm{c}$ & $15.68 \mathrm{~b}-\mathrm{e}$ \\
\hline \multirow{3}{*}{ 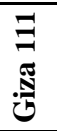 } & Control $\mathrm{H}_{2} \mathrm{O}$ & $47.8 \mathrm{c}-\mathrm{f}$ & $180.0 \mathrm{a}$ & 0.99 bc & $0.30 \mathrm{c}$ & $14.12 \mathrm{de}$ \\
\hline & MeJa $20 \mu \mathrm{M}$ & $101.8 \mathrm{a}$ & $169.9 \mathrm{~b}$ & $1.23 \mathrm{a}$ & $0.49 \mathrm{a}$ & $18.86 \mathrm{a}$ \\
\hline & SNP $500 \mu \mathrm{M}$ & $69.20 \mathrm{bc}$ & $130.5 \mathrm{~d}$ & $1.07 \mathrm{a}-\mathrm{c}$ & $0.33 \mathrm{c}$ & $15.76 \mathrm{~b}-\mathrm{e}$ \\
\hline
\end{tabular}

*Different letters indicate a significant difference at $\mathrm{p} \leq 0.05$ according to Duncan's multiple tests.

*F.wt. $=$ fresh weight, D.wt $=$ dry weight, seed index $=$ weight of 100 dry seeds

Table 3. Effect of foliar spray with MeJa and SNP on harvested soybean seed composition under natural infestation with cotton leaf worm.

\begin{tabular}{|c|c|c|c|c|c|}
\hline$\sum_{0}^{0} \approx$ & Treatments & $\begin{array}{c}\text { Total soluble } \\
\text { protein } \\
\mathrm{mg} / \mathrm{g}\end{array}$ & $\begin{array}{c}\text { Total soluble } \\
\text { sugars } \\
\mathrm{mg} / \mathrm{g}\end{array}$ & $\begin{array}{c}\text { Reducing sugars } \\
\mathrm{mg} / \mathrm{g}\end{array}$ & $\begin{array}{l}\text { Starch } \\
\mathrm{mg} / \mathrm{g}\end{array}$ \\
\hline \multirow{15}{*}{ 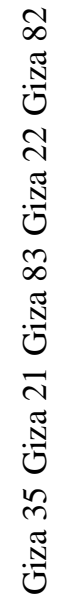 } & Control $\mathrm{H}_{2} \mathrm{O}$ & $45.9 \mathrm{n}$ & 11.451 & $0.516 \mathrm{e}-\mathrm{g}$ & $0.763 \mathrm{k}$ \\
\hline & MeJa $20 \mu \mathrm{M}$ & $101.0 \mathrm{fg}$ & $23.10 \mathrm{c}-\mathrm{e}$ & $0.640 \mathrm{c}-\mathrm{e}$ & $2.520 \mathrm{e}$ \\
\hline & SNP $500 \mu \mathrm{M}$ & $84.8 \mathrm{j}$ & $19.01 \mathrm{hi}$ & $0.280 \mathrm{hi}$ & $1.323 \mathrm{hi}$ \\
\hline & Control $\mathrm{H}_{2} \mathrm{O}$ & $50.8 \mathrm{n}$ & $13.31 \mathrm{k}$ & $0.106 \mathrm{j}$ & $0.887 \mathrm{k}$ \\
\hline & MeJa $20 \mu \mathrm{M}$ & $111.0 \mathrm{de}$ & $23.38 \mathrm{~b}-\mathrm{e}$ & $0.720 \mathrm{~b}-\mathrm{d}$ & $3.663 \mathrm{~d}$ \\
\hline & SNP $500 \mu \mathrm{M}$ & $87.0 \mathrm{ij}$ & $20.45 \mathrm{gh}$ & $0.386 \mathrm{gh}$ & $1.827 \mathrm{~g}$ \\
\hline & Control $\mathrm{H}_{2} \mathrm{O}$ & $58.5 \mathrm{~m}$ & $16.27 \mathrm{j}$ & $0.127 \mathrm{ij}$ & $1.143 \mathrm{j}$ \\
\hline & MeJa $20 \mu \mathrm{M}$ & $114.2 \mathrm{~d}$ & $24.0 \mathrm{~b}-\mathrm{d}$ & $0.773 \mathrm{bc}$ & $3.750 \mathrm{~cd}$ \\
\hline & SNP $500 \mu \mathrm{M}$ & $90.6 \mathrm{ij}$ & $20.78 \mathrm{~g}$ & $0.466 \mathrm{fg}$ & $1.820 \mathrm{~g}$ \\
\hline & Control $\mathrm{H}_{2} \mathrm{O}$ & 64.61 & $17.56 \mathrm{ij}$ & $0.146 \mathrm{ij}$ & $1.190 \mathrm{ij}$ \\
\hline & MeJa $20 \mu \mathrm{M}$ & $122.4 \mathrm{c}$ & $24.47 \mathrm{bc}$ & $0.810 \mathrm{~b}$ & $3.810 \mathrm{c}$ \\
\hline & SNP $500 \mu \mathrm{M}$ & $91.6 \mathrm{hi}$ & $21.47 \mathrm{fg}$ & $0.500 \mathrm{e}-\mathrm{g}$ & $2.110 \mathrm{f}$ \\
\hline & Control $\mathrm{H}_{2} \mathrm{O}$ & $71.2 \mathrm{k}$ & $18.28 \mathrm{i}$ & $0.190 \mathrm{ij}$ & $1.457 \mathrm{~h}$ \\
\hline & MeJa $20 \mu \mathrm{M}$ & $148.6 \mathrm{~b}$ & $24.79 \mathrm{~b}$ & $1.207 \mathrm{a}$ & $4.027 \mathrm{~b}$ \\
\hline & SNP $500 \mu \mathrm{M}$ & $97.4 \mathrm{gh}$ & $22.38 \mathrm{ef}$ & $0.517 \mathrm{e}-\mathrm{g}$ & $2.070 \mathrm{f}$ \\
\hline \multirow{3}{*}{$\stackrel{\mathbb{N}}{\mathcal{U}}=$} & Control $\mathrm{H}_{2} \mathrm{O}$ & 65.01 & $18.57 \mathrm{i}$ & $0.270 \mathrm{hi}$ & $1.387 \mathrm{~h}$ \\
\hline & MeJa $20 \mu \mathrm{M}$ & $162.9 \mathrm{a}$ & $27.22 \mathrm{a}$ & $1.347 \mathrm{a}$ & $5.720 \mathrm{a}$ \\
\hline & SNP $500 \mu \mathrm{M}$ & $105.8 \mathrm{ef}$ & $22.46 \mathrm{~d}-\mathrm{f}$ & $0.577 \mathrm{~d}-\mathrm{f}$ & $2.520 \mathrm{e}$ \\
\hline
\end{tabular}

*Different letters indicate a significant difference at $\mathrm{p} \leq 0.05$ according to Duncan's multiple tests.

Total soluble starch showed that significant differences among studied soybean cultivars, significant positive differences were observed among cultivars when treated with both MeJa and SNP treatments compared to its respective controls, significant differences for the two treatments were observed for all cultivars with an increase in starch content when soybean was treated with MeJa. Total protein, total soluble sugars, reducing sugars and total starch were decreased significantly in the susceptible genotypes comparing with the tolerant ones. On the other hand, MeJa and SNP treatments showed a 
significant increase in yield attributes and components as compared with untreated plants. Similar results was reported By Wilen $\boldsymbol{e t}$ al., 1991 who found that MeJa enhanced protein content in rapeseed and an increase in mRNA was detected comparing with untreated plants. Sultana et al. (2001) reported that the yield contributing characters of rice plants were increased by applying JA to stressed and unstressed plants. Raouf et al., (2012) showed that significant increase in essential oils of Agastache foeniculum was induced after 24 hours of treatment with $0.1 \mathrm{mM}$ of MeJa. SNP is currently being applied to plants exposed to stressful conditions in order to improve growth and yield (Farooq et al., 2009). The tolerant soybean genotypes contained higher amounts of protein. The synthesis and accumulation of a variety of storage proteins have been shown to be closely related to plant defense since several of these proteins present entomotoxic properties such as $\alpha$-amylase and proteinase inhibitors, lectins and globulins (Franco et al., 2002).

\section{Effect of MeJa and SNP on seed saturated fatty acids composition}

Total content and composition of saturated fatty acids of the six soybean cultivars are tabulated in table (4). Saturated fatty acids were much abundant in the tolerant and moderate genotypes as compared with the susceptible ones under natural infestation with cotton leaf worm. Both treatments (MeJa and SNP) caused an increment in saturated fatty acids as compared with their respective controls. Total saturated fatty acids were found to be divergent among soybean cultivars; the susceptible cultivars showed much more saturated fatty acid content than the tolerant ones.

\section{Effect of MeJa and SNP on seed unsaturated fatty acids composition}

Data recorded for unsaturated fatty acids composition is presented in table (5). Unsaturated fatty acids showed a wide variation in the six soybean genotypes. Generally, linoleic acid (C 18:2) and linolenic acid (C18:3) recorded lower values in the susceptible genotypes (Giza 82 and Giza 22), Giza111 recorded the highest values for (C 18:3) under different treatments. In addition, MeJa and SNP treatments induced increase in C 18:2 as compared with untreated plants with some exceptions in table (4). Both treatments were found to enhance Oleic acid (C 18:1) content compared to their respective untreated controls with an exception in Giza-83 and Giza-35 when treated with SNP. On the other hand, Arachidi acid (C 20:0) recorded higher values in the moderate and tolerant genotypes than in the susceptible ones. The total unsaturated fatty acids were lower in the sensitive genotypes (Giza-22 and Giza-82) as compared with the tolerant ones (Giza-35 and Giza-111). These findings are In harmony with Howe (2004) who reported that once plant tissues are damaged by chewing insects releasing of linolenic acid from intracellular membrane lipids of the affected tissues tacks place. Linolenic acid C18:3 is converted through octadecanoid pathway to green leaf volatiles like jasmonic acid (Unsicker et al., 2009) which considered as indirect inducible defense chemical that has been reported to deter insect attack in different plant systems (Wang et al., 2008). Hyun et al., (2008) supported the same observations, they concluded that when plant tissues are damaged by herbivores or mechanically $\mathrm{C} 18: 3$ fatty acids are released from the chloroplast membrane through the action of phospholipases, linolenic acid is oxidized to cause the accumulation of JA in herbivore-wounded plants (Smith et al., 2009). Tooker and De Moraes (2009) showed that, a tobacco bud worm caterpillar Heliothis virescens feeding caused an increase in the levels of linoleic and linolenic acid in damaged leaves compared to the undamaged controls. Arachidic acid were found to play an important role in wax and cuticle formation which are the first barrier in plant defense (Kachroo and Kachroo, 2009). Fatty acids play a vital role in membrane fluidity and they are involved in controlling plant defense against pathogens and pests (Heldt, 2005). The modulation of membrane fluidity and stability by regulating seed oil fatty acid composition may allow plants to adapt to various stresses (Upchurch, 2008). Goldhaber-Pasillas et al., (2014) who reported the polyunsaturation of fatty acids has proven to be correlated to adaptation when plants are challenged in response to biotic and abiotic stress.

\section{Retrotransposon based markers}

A set of eight IRAP and iPBS primers based on the conservative regions of retrotrarsposones were used for this study (Fig. 2). Retrotransposons based primers successfully distinguished soybean cultivars with 142 bands, out of which 24 were monomorphic and 118 were polymorphic Table (6) and Figure (2), Thirty seven unique markers were distinguished that characterized their respective genotypes with twenty three positive and fourteen negative specific markers (Table 6). These results are inagreement with BrownGuedira et al., 2000, Wang et al., 2006a, Mulato et al., 2010 and Kumawat et al., (2015) who succeeded in distinguishing a larg set of soybean accessions using simple sequence repeat markers (SSRs). Complete description of existing certified soybean varieties and patterns of genetic diversity could facilitate introgression of diverse germplasm into the current commercial soybean genetic base (Satyavathi et al., 2006).

Retrotransposon based markers succeeded to distinguish tolerant and sensitive cultivars with 19 markers resulted from five out of the eight tested primers (Table 7), four primers distinguished sensitive genotypes (Giza-22 and Giza-82) with positive markers ie iPBS-2399, IRAP-4314, IRAP-4364 and IRAP-4361. On the other hand the two sensitive genotypes were distinguished with positive markers generated from the two IRAP primers IRAP-4341 and 
IRAP-4377. It worthy to mention that IRAP-4377 generated the highest number of markers (13 markers) that positively identified the two tolerant genotypes while there were completely absent in the two sensitive ones, this primer is considered highly informative in distinguishing tolerant form sensitive soybean cultivars.

The genetic diversity has a great significance for planning an efficient breeding programme for crop improvement (Chandra et al., 2013). The assessment of genetic diversity is not only important for crop improvement efforts but also for the efficient management and protection of available genetic variability. Molecular profiling has been the preferred choice for breeders as these are more reliable, authentic and less influenced by environmental fluctuations (Vinu et al., 2013). Several retrotransposons have been shown to be highly polymorphic for insert location within plant species (Porceddu et al., 2002). These properties have been exploited in several molecular marker systems for genetic analysis in a range of cereal grass and grain legume species (Porceddu et al., 2002). The effectiveness of IRAP, REMAP, SSR, and ISSR markers were investigated to assess genetic diversity among and within eight Medicago sativa $\mathrm{L}$. populations. IRAP markers generated the maximum proportion of polymorphic loci per primer (Mandoulakani et al., 2012).

The pair similarity coefficient among the six soybean cultivars ranged from 21 to $71 \%$ (table 8). The highest similarity value $(71 \%)$ was observed between the two tolerant cultivars Giza-35 and Giza111 , while the lowest similarity value $(21 \%)$ was observed between Giza-35 (tolerant) and Giza-82 (sensitive), genetic similarity was found to be $46 \%$ between the two sensitive cultivars Giza-22 and Giza82 . The genetic base of soybean cultivars is considered to be extremely narrow (Hymowitz 1970). Cluster analysis performed using unweighted pair-group method of arithmetic means (UPGMA) expressing the relationships among studied soybean cultivars is illustrated in figure (3). The cluster analysis resolved the six soybean cultivars into two main clusters (A and B). The first, cluster (A) comprised only Giza-82 (sensitive), the second cluster (B) contains two subcluster $(\mathrm{C}$ and $\mathrm{D})$ the first $(\mathrm{C})$ have Giza-22 which is the second sensitive genotypes, the two sensitive genotypes were genetically correlated with $46 \%$ similarity and were located nearest to each other in the resulted dendrogram, cluster (D) was divided into two sub-clusters (E and F) sub-cluster $\mathrm{E}$ has Giza-83 (moderate) while sub-cluster $(\mathrm{F})$ was divided into two sub-clusters ( $\mathrm{G}$ and $\mathrm{H})$ the first has Giza-21 (moderate) and the second has the most tolerant cultivars Giza-35 and Giza-111. Long terminal repeatretrotransposons (LTR-RTs) are the most abundant genomic components in flowering plants, making up a large fraction of all plant genomes so far investigated (Du et al., 2010). Mulato et al., 2010 investigated the genetic variation in 79 soybean (Glycine max) accessions using thirty SSR primer-pairs. All analyzed loci were polymorphic and 259 alleles were found. The genetic diversity observed was high and allowed the formation of five groups and several subgroups. A moderate relationship between genetic divergence and geographic origin of accessions was observed. Eleven SSR primer pairs could amplify polymorphic SSRs from 25 soybean genotypes. These eleven SSR markers successfully distinguished 23 of the 25 soybean genotypes, with the exception of a pair of closely related breeding lines from the same cross Mulato et al., 2010. Genetic relationships among accessions are helpful for designing future breeding efforts for yield, quality and pest resistance improvement (Wang et al., 2006a). 
Table 4. Effect of foliar spray with MeJA and SNP on saturated fatty acid composition in soybean seeds under field condition of natural infestation with cotton leaf worm.

\begin{tabular}{|c|c|c|c|c|c|c|c|c|c|c|c|c|c|c|c|c|c|c|}
\hline \multirow{2}{*}{ Fatty acids } & \multicolumn{3}{|c|}{ Giza 82} & \multicolumn{3}{|c|}{ Giza 22} & \multicolumn{3}{|c|}{ Giza 83} & \multicolumn{3}{|c|}{ Giza 21} & \multicolumn{3}{|c|}{ Giza 35} & \multicolumn{3}{|c|}{ Giza 111} \\
\hline & Cont. & MeJA & SNP & Cont. & MeJA & SNP & Cont. & MeJA & SNP & Cont. & MeJA & SNP & Cont. & MeJA & SNP & Cont. & MeJA & SNP \\
\hline C :8 Capryliac acid & 0.00 & 0.00 & 0.20 & 0.00 & 0.00 & 1.51 & 18.50 & 0.00 & 0.00 & 0.00 & 0.00 & 0.00 & 0.00 & 0.00 & 0.87 & 1.19 & 0.00 & 0.88 \\
\hline $\mathrm{C}: 10$ Capric acid & 0.00 & 0.00 & 0.05 & 0.00 & 0.00 & 0.66 & 0.82 & 0.00 & 0.49 & 0.00 & 0.00 & 0.00 & 0.00 & 0.00 & 1.40 & 1.67 & 0.00 & 1.06 \\
\hline $\mathrm{C}: 11$ Undecanoic acid & 0.00 & 0.00 & 0.60 & 0.10 & 0.00 & 11.55 & 4.80 & 2.30 & 0.00 & 0.00 & 0.00 & 0.00 & 0.00 & 0.00 & 9.90 & 0.00 & 0.00 & 7.53 \\
\hline $\mathrm{C}: 12$ Lauric acid & 0.00 & 0.32 & 1.43 & 0.44 & 0.50 & 1.84 & 1.10 & 5.36 & 4.40 & 2.00 & 1.60 & 0.24 & 0.11 & 0.48 & 2.89 & 2.49 & 0.27 & 1.59 \\
\hline $\mathrm{C}: 13$ Tridecanoic acid & 0.00 & 0.00 & 0.07 & 1.32 & 1.29 & 3.28 & 2.36 & 3.09 & 0.16 & 1.84 & 2.71 & 1.17 & 0.00 & 2.14 & 2.70 & 6.73 & 0.46 & 2.44 \\
\hline $\mathrm{C}: 140$ Myrisitic acid & 8.67 & 2.25 & 0.00 & 1.08 & 0.00 & 0.00 & 0.00 & 7.20 & 9.03 & 4.96 & 6.15 & 0.00 & 0.38 & 0.00 & 1.45 & 1.30 & 0.00 & 0.00 \\
\hline $\mathrm{C}: 14$ 1Myristoleic acid & 20.65 & 0.00 & 2.97 & 0.00 & 2.59 & 2.38 & 2.46 & 3.77 & 9.97 & 11.35 & 7.13 & 1.01 & 0.92 & 1.74 & 0.79 & 1.05 & 0.55 & 1.89 \\
\hline $\begin{array}{l}\mathrm{C}: 15 \text { 1Cis-10-pentadecanoic } \\
\text { acid }\end{array}$ & 8.37 & 0.86 & 2.22 & 0.68 & 1.73 & 0.00 & 2.13 & 3.77 & 6.77 & 5.84 & 0.00 & 1.11 & 0.00 & 1.83 & 0.43 & 0.00 & 0.50 & 1.12 \\
\hline $\mathrm{C}: 16 \quad 0$ Palmitic acid & 9.65 & 13.48 & 16.36 & 0.83 & 1.63 & 0.00 & 1.35 & 9.84 & 0.00 & 4.49 & 3.32 & 0.89 & 0.46 & 0.00 & 0.00 & 0.00 & 0.33 & 0.63 \\
\hline $\mathrm{C}: 17$ 0 Heptadecanoic acid & 0.00 & 0.00 & 2.47 & 0.22 & 0.00 & 0.97 & 0.00 & 0.00 & 0.00 & 0.00 & 0.00 & 0.00 & 0.00 & 0.00 & 1.18 & 0.60 & 0.00 & 0.20 \\
\hline $\mathrm{C}: 200$ Arachidic acid & 0.00 & 0.00 & 0.00 & 0.00 & 1.37 & 0.00 & 2.02 & 0.00 & 0.00 & 0.78 & 0.00 & 2.25 & 0.92 & 1.94 & 0.00 & 1.68 & 0.00 & 10.68 \\
\hline $\mathrm{C}: 210$ Henicosanoic acid & 0.00 & 0.00 & 0.00 & 0.00 & 1.22 & 8.37 & 1.80 & 0.00 & 0.00 & 1.35 & 0.00 & 0.00 & 0.00 & 0.00 & 1.80 & 0.00 & 0.17 & 3.04 \\
\hline $\mathrm{C}: 220$ Behenic acid & 0.00 & 0.98 & 0.00 & 0.00 & 0.00 & 3.49 & 0.00 & 0.00 & 0.00 & 1.96 & 0.00 & 0.00 & 0.00 & 0.00 & 2.96 & 1.90 & 0.00 & 1.59 \\
\hline $\mathrm{C}: 230$ Tricosanoic acid & 0.00 & 0.00 & 0.55 & 51.34 & 0.43 & 0.00 & 0.32 & 0.00 & 0.00 & 0.00 & 0.00 & 0.00 & 0.00 & 0.00 & 1.96 & 1.77 & 0.11 & 0.73 \\
\hline \% Saturated fatty acids & 47.33 & 17.89 & 26.93 & 56.01 & 10.76 & 34.06 & 35.64 & 35.32 & 31.22 & 33.80 & 20.91 & 5.13 & 2.78 & 8.14 & 28.34 & 20.37 & 2.38 & 33.38 \\
\hline
\end{tabular}

Table 5. Effect of foliar spray with MeJA and SNP on unsaturated fatty acid composition in soybean harvested seeds under field condition of natural infestation with cotton leaf worm.

\begin{tabular}{|c|c|c|c|c|c|c|c|c|c|c|c|c|c|c|c|c|c|c|}
\hline \multirow[b]{2}{*}{ Fatty acids } & \multicolumn{3}{|c|}{ Giza 82} & \multicolumn{3}{|c|}{ Giza 22} & \multicolumn{3}{|c|}{ Giza 83} & \multicolumn{3}{|c|}{ Giza 21} & \multicolumn{3}{|c|}{ Giza 35} & \multicolumn{3}{|c|}{ Giza 111} \\
\hline & Cont. & MeJA & SNP & Cont & MeJA & SNP & Cont & MeJA & SNP & Cont & MeJA & SNP & Cont & MeJA & SNP & $\begin{array}{c}\text { Cont } \\
.\end{array}$ & MeJA & SNP \\
\hline $\mathrm{C}: 16$ 1 Palmitolic acid & 0.00 & 0.00 & 0.00 & 5.96 & 2.20 & 0.99 & 10.17 & 0.00 & 10.18 & 0.00 & 0.00 & 9.22 & 7.82 & 0.00 & 0.00 & 0.00 & 0.00 & 0.00 \\
\hline C:17 1 Cis-10-heptadecanoic acid & 0.00 & 0.00 & 0.13 & 0.12 & 0.00 & 0.00 & 0.24 & 0.00 & 0.00 & 0.52 & 0.00 & 0.12 & 0.00 & 0.00 & 0.00 & 1.84 & 0.00 & 0.29 \\
\hline $\mathrm{C}: 18$ 1 Oleic acid & 22.47 & 71.29 & 65.38 & 33.32 & 70.78 & 38.37 & 35.44 & 34.15 & 29.75 & 28.14 & 34.75 & 48.84 & 51.22 & 53.11 & 14.93 & 0.00 & 0.00 & 1.85 \\
\hline $\mathrm{C}: 18$ 2n Linoleic acid & 0.00 & 0.00 & 0.00 & 0.00 & 0.00 & 2.31 & 7.29 & 25.55 & 24.03 & 25.61 & 29.11 & 26.64 & 30.23 & 31.30 & 37.90 & 0.00 & 0.00 & 28.32 \\
\hline $\mathrm{C}: 18$ 3n3 Linolenic acid & 0.00 & 8.00 & 6.70 & 3.30 & 13.34 & 15.72 & 4.70 & 2.58 & 3.69 & 4.29 & 12.03 & 6.18 & 6.56 & 6.66 & 0.00 & 63.10 & 96.19 & 29.13 \\
\hline $\mathrm{C}: 20$ 36t Eicosadienoic acid & 0.00 & 0.93 & 0.41 & 0.00 & 0.00 & 0.00 & 2.61 & 0.38 & 0.00 & 4.02 & 0.00 & 0.87 & 0.00 & 0.78 & 5.46 & 0.00 & 0.65 & 5.88 \\
\hline $\mathrm{C}: 204$ Arachidonic acid & 0.00 & 0.00 & 0.00 & 0.38 & 1.61 & 0.95 & 0.00 & 0.00 & 0.40 & 0.00 & 0.00 & 0.71 & 0.90 & 0.00 & 5.14 & 5.07 & 0.00 & 0.00 \\
\hline $\mathrm{C}: 205$ Eicosapentaenoic acid & 0.00 & 0.00 & 0.47 & 0.00 & 0.00 & 0.00 & 0.00 & 0.00 & 0.00 & 0.00 & 0.00 & 0.10 & 0.00 & 0.00 & 0.00 & 2.54 & 0.00 & 0.00 \\
\hline $\mathrm{C}: 221$ Erucic acid & 3.02 & 1.89 & 0.00 & 0.91 & 1.31 & 7.61 & 1.89 & 2.02 & 1.13 & 2.84 & 3.20 & 0.64 & 0.49 & 0.00 & 8.23 & 7.07 & 0.78 & 1.15 \\
\hline \% Unsaturated fatty acids & 52.67 & 82.11 & 73.07 & 44.00 & 89.24 & 65.94 & 64.36 & 64.68 & 68.78 & 66.20 & 79.09 & 94.87 & 97.22 & 91.86 & 71.66 & 79.63 & 97.62 & 66.62 \\
\hline
\end{tabular}


Table 6. Total number of bands, monomorphic, polymorphic, Positives and negative unique bands generated by testing IRAP and iPBS markers tested on six soybean cultivars.

\begin{tabular}{|c|c|c|c|c|c|c|c|c|}
\hline \multirow[b]{2}{*}{ primer } & \multirow[b]{2}{*}{ Monomorphic bansd } & \multirow[b]{2}{*}{ polymorphic bands } & \multirow{2}{*}{$\begin{array}{c}\text { Total } \\
\text { bands }\end{array}$} & \multicolumn{4}{|c|}{ Specific markers } & \multirow{2}{*}{$\begin{array}{c}\text { Total } \\
\text { markers/ } \\
\text { primer }\end{array}$} \\
\hline & & & & Positive makers & genotypes & Negative marker & genotypes & \\
\hline & & & & 250 & Giza83 & 200 & Giza82 & 7 \\
\hline & & & & 500 & Giza111 & 620 & Giza83 & \\
\hline \multirow[t]{5}{*}{ iPBS-2394 } & 1 & 17 & 18 & 1031 & Giza83 & & & \\
\hline & & & & 1250 & Giza83 & & & \\
\hline & & & & 1700 & Giza22 & & & \\
\hline & & & & 150 & Giza21 & & & 6 \\
\hline & & & & 360 & Giza82 & & & \\
\hline \multirow{4}{*}{ iPBS-2399 } & & & & 600 & Giza22 & & & \\
\hline & 3 & 17 & 20 & 1070 & Giza21 & & & \\
\hline & & & & 2100 & Giza82 & & & \\
\hline & & & & 2200 & Giza22 & & & \\
\hline IRAP-4341 & 2 & 10 & 12 & 250 & Giza83 & & & 1 \\
\hline \multirow{4}{*}{ iPBS-2219 } & & & & 230 & Giza111 & & & 2 \\
\hline & 3 & 17 & 20 & 900 & Giza83 & & & \\
\hline & & & & 500 & Giza82 & 450 & Giza21 & 8 \\
\hline & & & & 1220 & Giza82 & 640 & Giza82 & \\
\hline \multirow[t]{5}{*}{ IRAP-4364 } & 8 & 13 & 21 & 1310 & Giza21 & 940 & Giza82 & \\
\hline & & & & & & 1100 & Giza82 & \\
\hline & & & & & & 2100 & Giza82 & \\
\hline & & & & 500 & Giza82 & 600 & Giza35 & 6 \\
\hline & 5 & 9 & & 1031 & Giza22 & 660 & Giza35 & \\
\hline \multirow{2}{*}{ IRAP-4368 } & 5 & 9 & 14 & & & 700 & Giza35 & \\
\hline & & & & & & 900 & Giza22 & \\
\hline \multirow{2}{*}{ IRAP-4377 } & 2 & 20 & 22 & 1031 & Giza82 & 1050 & Giza82 & 2 \\
\hline & 2 & 20 & 22 & 2700 & Giza83 & & & \\
\hline \multirow{2}{*}{ IRAP-4361 } & & & & 350 & Giza35 & 400 & Giza82 & 2 \\
\hline & 0 & 15 & 15 & 1650 & Giza53 & 500 & Giza83 & \\
\hline Yrand Total & 24 & 118 & 142 & 23 & & 14 & & 37 \\
\hline
\end{tabular}


Table 7. Positive and negative unique bands identified for tolerant and sensitive soybean genotypes using IRAP and iPBS markers.

$\begin{array}{cccc}\text { NO } & \text { Primer } & \text { Marker size (bp) } & \text { tolerance } \\ 1 & \text { iPBS-2399 } & 1200 & -- \\ 2 & & 1250 & -- \\ 3 & \text { IRAP-4341 } & 580 & ++ \\ 4 & \text { IRAP-4364 } & 520 & -- \\ 5 & & 750 & ++ \\ 6 & & 480 & ++ \\ 7 & & 580 & ++ \\ 8 & & 680 & ++ \\ 9 & & 740 & ++ \\ 10 & & \mathbf{8 0 0} & ++ \\ 11 & & 1100 & ++ \\ 12 & & 1230 & ++ \\ 13 & & 1400 & ++ \\ 14 & & 1500 & ++ \\ 15 & & 1600 & ++ \\ 16 & & 1900 & ++ \\ 17 & & 2000 & ++ \\ 19 & & 3300 & +-\end{array}$

$++=$ positive marker for both genotypes, tolerant genotypes Giza-35, Giza-111 and sensitive genotypes Giza-22, Giza-82 
Table 8. Genetic similarity matrix between the six soybean genotypes computed according to IRAP and iPBS data.

\begin{tabular}{|c|c|c|c|c|c|c|}
\hline Genotypes & 1. Giza21 & 2. Giza22 & 3. Giza35 & 4. Giza82 & 5. Giza83 & 6. Giza111 \\
\hline \multicolumn{7}{|l|}{ 1. Giza21 } \\
\hline 2. Giza22 & 0.50 & & & & & \\
\hline 3. Giza35 & 0.60 & 0.57 & & & & \\
\hline 4. Giza82 & 0.39 & 0.46 & 0.21 & & & \\
\hline 5. Giza83 & 0.53 & 0.42 & 0.60 & 0.36 & & \\
\hline 6. Giza111 & 0.67 & 0.61 & 0.71 & 0.34 & 0.58 & \\
\hline
\end{tabular}

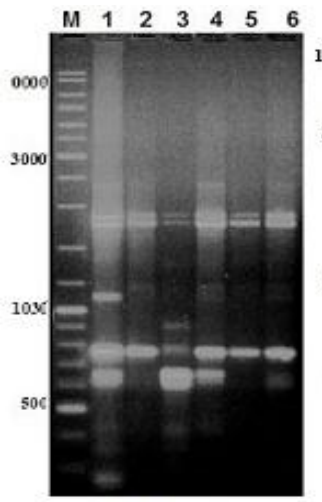

iPBS-2219

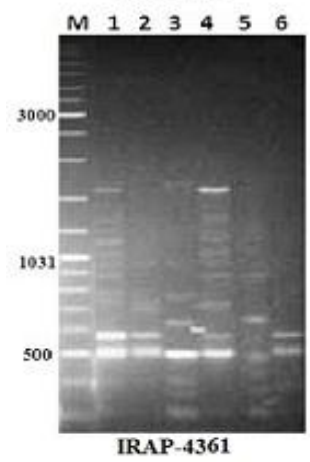

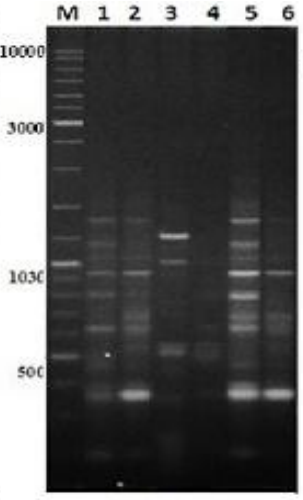

iPBS-2394

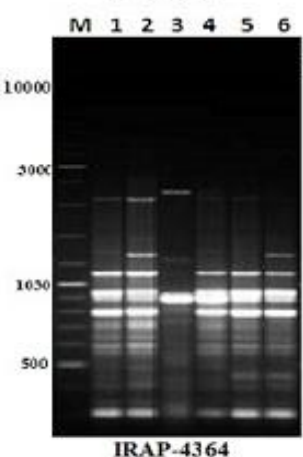

IRAP-4364

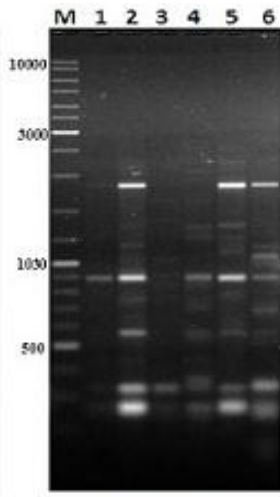

iPBS-2399

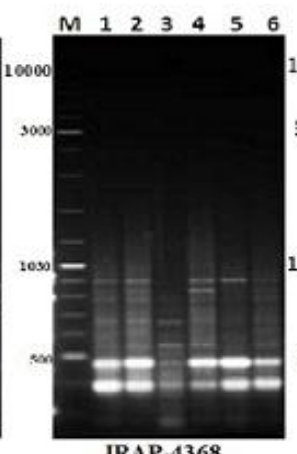

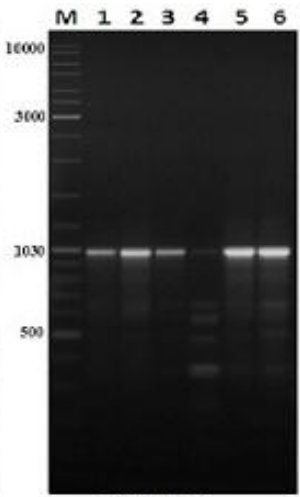

IRAP-4341

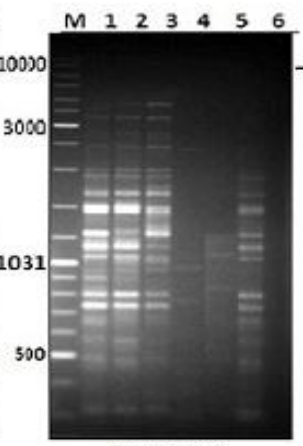

IRAP-4377

Figure (2): IRAP and iPBS PCR polymorphism of DNA for six soybean (1, 2, 3, 4, 5 and 6) genotypes using IRAP and iPBS primers, (M) refer to DNA ladder $10000 \mathrm{pb}$ DNA ladder
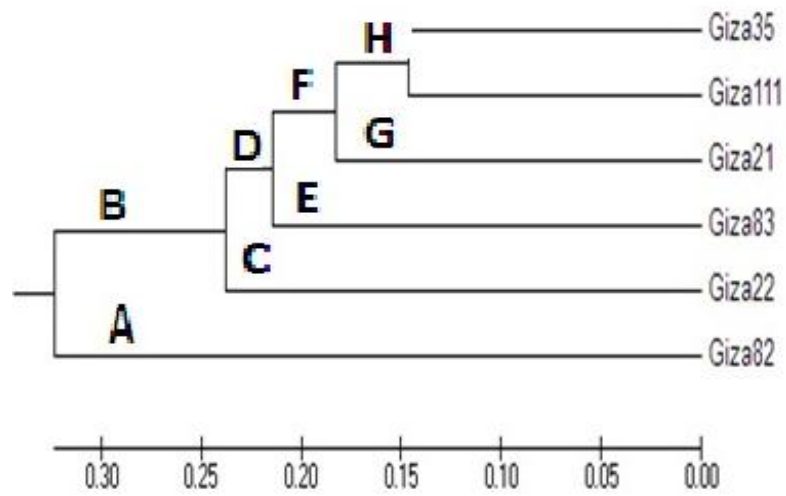

Figure 3. A dendrogarm for six soybean genotypes constructed from the IRAP marker data using un weighted pair group method with arithmetic mean (UPGMA).

\section{Conclusion}

From the results obtained in this investigation it could be concluded that methyl jasmonate and sodium nitroprusside treatments have positive effects on enhancing soybean tolerance to infestation with cotton leaf worm. Both treatments were found to induce significant decrease in leaf eaten area by cotton leaf worm which combined with significant increment in yield and yield components. In addition MeJa $(20 \mu \mathrm{M})$ treatment recorded better results comparing with SNP $(500 \mu \mathrm{M})$. Our results showed that, Giza-35 and Giza111 genotypes were more tolerant to cotton leaf worm 
infestation as compared with susceptible genotypes Giza-82 and Giza-22. Retotransposon-based markers (IRAP and iPBS) succeeded to differentiate tolerant and sensitive six cultivars.

\section{Acknowledgment}

The authors are grateful to FCRI (Field Crop Research Institutes) for providing soybean cultivars for molecular studies and data analysis and to Ain Shams University, Faculty of Education for physiological studies.

\section{References}

A.O.A.C. (1984): Official methods of analysis $14^{\text {th }} \mathrm{ed}$. association of analytical chemists Washington, DC, Association of Official Analytical Chemists.

Abouelghar, G.E., Sakr, H., Ammar, H.A., Yousef A. and Nassar, M. (2013): Sublethal effects of spinosad (tracer®) on the cotton leaf worm (Lepidoptera: noctuidae). Journal of Plant Protection Research, 53(3): pp.1-10.

Akladious, S.A. and Mohamed, H.I. (2017): Physiological role of exogenous nitric oxide in improving performance, yield and some biochemical aspects of sunflower plant under zinc stress. Acta Biologica Hungarica. 68(1): 01-114.

Brown-Guedira, G.L., Thompson, J. A. and Warburton, M. L. (2000): Evaluation of genetic diversity of soybean introductions and north american ancestor using RAPD and SSR markers. Crop science, 40: 815 - 823 .

Chandra, V., Pant, U., Bhajan, R., and Singh, A. K. (2013): Studies on genetic diversity among Alternaria blight tolerant indian mustard genotypes using SSR markers. The Bioscan 8(4):1431-1435.

Deng, F. (2005): Effects of glyphosate, chlorsulfuron, and methyl jasmonate on growth and alkaloid biosynthesis of jimson weed (Datura stramonium L.). Pesticide Biochemistry and Physiology, 82(1): 6-26.

Dey, P.M. (1990): Methods in plant biochemistry.Vol-II. carbohydrates. (Publ.) Acad. Press London.

Du, J., Tian, Z., Hans, C.S., Laten, H.M., Cannon, S.B., Jackson, S.A., Shoemaker, R.C. and Ma, J. (2010): Evolutionary conservation, diversity and specificity of LTR retrotransposons in flowering plants: insights from genome-wide analysis and multi-specific comparison. Plant journal, 63(4): 584-98.

Dubois, M., Gilles, K.A. and Hamilton, J.K. (1956): Colorimetric method for determination of sugars and related substances. Analytical Chemistry, 28(3): 350-356.

Duncan, B.D. (1955): Multiple ranges and multiple F. Test. Biometrics II: 1- 42.

Farooq, M., Basra, S.M.A., Wahid, A. and Rehman, H. (2009): Exogenously nitric oxide enhances the drought tolerance in fine grain aromatic rice (Oryza sativa L.). Journal Agronomy and Crop Science, 195(4): 254-261.

Filippou, P., Antoniou, C. and Fotopoulos, V. (2013): The nitric oxide donor sodium nitroprusside regulates polyamine and proline metabolism in leaves of Medicago truncatula plants. Free Radical Biology and Medicine, 56: $172-183$.

Flavell, R.B., Bennett, M.D., Smith, J.B. and Smith, D.B. (1974): Genome size and proportion of repeated nucleotide DNA sequence in plants. Biochemical Genetics, 12: 257-269.

Franco, O.L., Rigden, D.J., Melo, F.R. and Grosside-Sá, M. F. (2002): Plant alpha-amylase inhibitors and their interaction with insect alphaamylases-structure, function and potential for crop protection. European Journal of Biochemistry, 269(2): 397-412.

Garcia-Mata, C. and Lamattina, L. (2007): Abscisic acid (ABA) inhibits light induced stomatal opening through calcium- and nitric oxide-mediated signaling pathways. Nitric Oxide, 17(3): 143-151.

Glass, R. L. (1971): Alcoholysis, saponification and the preparation of fatty acid methyl esters. Lipids 6(12): 919-925.

Goldhaber-Pasillas, G.D., Mustafa, N. R. and Erpoorte, R. V. (2014): Jasmonic acid effect on the fatty acid and terpenoid indole alkaloid accumulation in cell suspension cultures of Catharanthus roseus. Molecules 19:10242-10260.

Golenberg, E.M., Giannasi, D.E., Clegg, M.T., Smiley, C.J., Durbin, M., Henderson, D. and Zurawski, G. (1990): Chloroplast DNA sequence from a Miocene Magnolia species. Nature. 344: 656-658.

Gomez, K.A. and Gomez, A.A. (1984): Statistical procedures for agricultural research. Wiley, Singapore, 680.

Gozukirmizi, N., Yilmaz, S., Marakli, S. and Temel, A. (2015): Retrotransposon-based molecular markers; tools for variation analysis in plants. In book: Applications of molecular markers in plant genome analysis and breeding, 2015, Chapter: 2. Publisher: Research Signpost, Editors: Ksenija Taški-Ajduković, 19-44

Gurley, W.B., Hepburn, A.G. and Key, J.L. (1979): Sequence organization of the soybean genome. Biochimica et Biophysica Acta , 561:167-183.

Hartree, E.F. (1972): Determination of protein: A modification of the Lowry method that gives a linear photometric response. Analytical biochemistry, 48(2): 22-427.

Heldt, H.W. (2005): Plant biochemistry. Elsevier Academic Press. San Diego, California 921014495, USA.

Howe, G.A. (2004): Jasmonates as signals in the wound response. Plant growth regulation, 23(3): 223-237. 
Hymowitz, T. (1970): On the domestication of the soybean. Economic Botany, 24: 408-421.

Hyun, Y., Choi, S., Hwang, H., Yu, J., Nam, S., Ko, J., Park, Y., Seo, Y.S., Kim, E.Y., Ryu, S.B., Kim, W.T., Lee, Y., Kang, H. and Lee, I. (2008): Cooperation and functional diversification of two closely related galactolipase genes for jasmonate biosynthesis. Developmental Cell, 14(2): 183:192.

Kachroo, A. and Kachroo, P. (2009): Fatty acidderived signals in plant defense. Annual Review of Phytopathology, 47: pp.153-176.

Kasopers, H. (1965): Erorterungen zür prüfung von Fungiziden in obsthau. Pflanzensc-hutzNachrichten. "Bayer". 18: 83-92

Kates, M. and Eberhardt, F.M. (1957): Isolation and fractionation of leaf phosphatides. Canadian Journal of Botany, 35: 895-905.

Klessig, D.F. J., Noad, R., Navarre, D.A., Wendehenne, D., Kumar, D., Zhou, J.M., Shali, S., Zhang, S., Kachroo, P., Trifa, Y., Pontier, D., Lam, E. and Silva, H. (2000): Nitric oxide and salicylic acid signaling in plant defense. Proceedings of the National Academy of Sciences, (USA), 97(16): 8849-8855.

Kumawat, G., Singh, G., Gireesh, C., Shivakumar, M., Arya, M., Dinesh, K.A., and Husain, M.S. (2015): Molecular characterization and genetic diversity analysis of soybean (Glycine max (L.) Merr.) germplasm accessions in India. Physiology and Molecular Biology of Plants, 21(1):101-107.

Lamattina, L., Garica-Mata, C., Graziano, M. and Pagnussat, G. (2003): Nitric oxide: The versatility of an extensive signal molecule. Annual Review of Plant Biology, 54: 109-136.

Lowry, O.H., Rosebrough, N.J., Farr, A.L. and Randall, R.J. (1951): Protein measurement with the Folin phenol reagent. Journal of Biological Chemistry, 193(1): pp.265-275.

Maltas, E., Dageri, N., Vural, C. H. and Yildiz, S. (2011): Biochemical and molecular analysis of soybean seed from Turkey. Journal of Medicinal Plants Research, 5: 1575-1581.

Mandoulakani, A.; Piri, B.; Darvishzadeh, Y.; Bernousi, R. I.; Jafari, M. (2012). Retroelement insertional polymorphism and genetic diversity in Medicago sativa populations revealed by IRAP and REMAP markers. Plant Molecular Biology Reporter, 30: 286-296.

Massouda, A. H.; Aly, S. D.; El-Shshtawayb, H.; Sleemb, F. M. (2014). Efficancy, persistence and removal of chlorpyrifos-methyl after application against cotton leaf worm in soybean. Journal of Materials and Environmental Science, 5: 13981405.

Miller, G.L. (1959): Use of dinitro salicylic acid reagentfor determination of reducing sugar. Analytical Chemistry, 31: pp.426-428.

Mohamed, H. I.; Latif, H. H. (2017). Improving the tolerance of soybean genotypes to water stress by foliar application with methyl jasmonate.
Physiology and molecular biology of plants. 23 (3):545-556.

Mohamed, H. I.; Abd-El Hameed, A. G. (2014). Molecular and biochemical markers of some Vicia faba L. genotypes in response to storage insect pests infestation. Journal of Plant Interactions. 9: 618-626.

Mulato, B. M.; Möller, M.; Zucchi, M. I.; Quecini, V.; Pinheiro, J. B. (2010). Genetic diversity in soybean germplasm identified by SSR and ESTSSR markers. Pesquisa Agropecuária Brasileira, 45(3): 276-283.

Myers, S. W.; Hogg, D. B. and Wedberg, J. L. (2005). Determining the optimal timing of foliar insecticide applications for control of soybean aphid (Hemiptera: Aphididae) on Soybean. Journal of Economic Entomology, 98: 2006-2012.

Pearce, S. R.; Harrison, G.; Li, D.; HeslopHarrison, J. S.; Kumar, A.; Flavell, A. J. (1996). The Ty1- copia group retrotransposons in Vicia species: copy number, sequence heterogeneity and chromosomal localisation. Molecular \& General Genetics , 250: 305-315.

Porceddu, A.; Albertini, E.; Barcaccia, G.; Marconi, G.; Bertoli, F. B.; Veronesi, F. (2002) Development of S-SAP markers based on an LTRlike sequence from Medicago sativa L. Molecular Genetics and Genomics 267:107-114.

Raouf, F. F.; Omidbaigi, R.; Sharifi, M.; Sefidkon, F.; Behmanesh, M. (2012). Effect of methyl jasmonate on essential oil content and composition of Agastache foeniculum. Journal of medicinal plants research, 6: 5701-5705.

Rohlf, F. J. (1993). NTSYs-pc- Numerical taxonomy and multivariate analysis. Applied Biostatics., New York, USA. pp.15.

Rose, R.; Rose, C.L.; Omi, S.K.; Forry, K.R.; Durall, D.M. and Bigg, W.L. (1991): Starch determination by perchloric acid vs enzymes: evaluating the accuracy and precision of six colorimetric methods. Journal of Agricultural Food Chemistry, 39: pp.2-11.

SanMiguel, P.; Tikhonov, A.; Jin, Y-K.; Motchoulskaia, N.; Zakharov, D.; MelakeBerhan, A.; Springer, P. S.; Edwards, K. J.; Lee, M.; Avramova, Z.; Bennetzen, J. L. (1996). Nested retrotransposons in the intergenic regions of the maize genome. Science 274:765-768.

Satyavathi C. T.; Bhat, K. V.; Bharadwaj, C.; Tiwari, S. P.; Chaudhury, V. K. (2006). AFLP analysis of genetic diversity in Indian soybean (Glycine $\max$ (L.) Merr.) varieties. Genetic Resources and Crop Evolution, 53: 1069-1079.

Smith, J. L.; De Moraes, C. M.; Mescher, M. C. (2009). Jasmonate and salicylate mediated plant defense responses to insect herbivores, pathogens and parasitic plants. Pest Management Science, 65(5): 497-503.

SoyStats (2011). American soybean association. Available at http://soystats.com , St. Louis,USA 
Krishnan H.B.2000: Biochemistry and molecular biology of soybean seed storage proteins. New Seeds 2000, 2: 1-25.

Sultana, N.; Ikeda, T.; Kashem, M. A. (2001). Effect of foliar spray of nutrient solutions on photosynthesis, dry matter accumulation and yield in seawater-stressed rice. Environmental and Experimental Botany, 46: 129-140.

Thaler, J. S.; Stout, M. J.; Karban, R.; Duffey, S. S. (2001): Jasmonate-mediated induced plant resistance affects a community of herbivores. Ecological Entomology, 26(3): 312-324.

Tooker, J. F.; De Moraes, C.M. (2009). A gallinducing caterpillar species increases essential fatty acid content of its host plant without concomitant increases in phytohormone levels. Molecular Plant-Microbe Interactions, 22(5): pp.551-559.

Unsicker, S. B.; Kunert, G.; Gershenzon, J. (2009). Protective perfumes: the role of vegetative volatiles in plant defense against herbivores. Current Opinion in Plant Biology, 12(4): 479-485.

Upchurch, R. G. (2008). Fatty acid unsaturation, mobilization, and regulation in the response of plants to stress. Biotechnology Letters, 30(6): 967977.

Vicient, C. M.; Suoniemi, A.; AnamthawatJonsson, K.; Tanskanen, J.; Beharav, A.; Nevo, E.; Schulman, A. H. (1999). Retrotransposon BARE-1 and its role in genome evolution in the genus Hordeum. Plant Cell, 11:1769-1784.

Vinu, V.; Singh, N.; Vasudev, S.; Yadava, D. K.; Kumar, S.; Naresh, S.; Bhat, S. R.; Prabhu, K.
V. (2013). Assessment of genetic diversity in Brassicaceae (Brassica juncea) genotypes using phenotypic differences and SSR markers. Revista de Biología Tropical, 61(4):1919-1934.

Voytas, D. F.; Cummings, M. P.; Konieczny, A.; Ausubel, F. M.; Rodermel, S. R. (1992). copia like retrotransposons are ubiquitous among plants. Proceedings of the National Academy of Sciences USA, 89:7124-7128.

Wang, L.; Guan, R.; Zhangxiong, L.; Chang, R.; Qiu, L. (2006a). Genetic diversity of Chinese cultivated soybean revealed by SSR markers. Crop Science, 46: 1032-1038.

Wang, H.; Guo, W. F.; Zhang, P. J.; Wu, Z. Y.; Liu, S. S. (2008): Experience-induced habituation and preference towards non-host plant odors in ovipositing females of a moth. Journal of Chemical Ecology, 34(3): 330-338.

Wilen, R. W.; Van Rooijen, G. J. H.; Pearce, D. W; Pharis, R. P.; Holbrook, L. A.; Moloney, M. M. (1991). Effects of jasmonic acid on embryospecific processes in brassica and linum oil seeds. Plant Physiology, 95: 399-405.

Zayed, E. M. (2007). Improvement of soybean plant by genetic engineering techniques. Ph. D GEBRI (Genetic Engineering and Biotechnology Institute). Sadat City, Munofiya University, Egypt.

Zein, I.; Jawhar, M.; Arabi, M. I. E. (2010). Efficiency of IRAP and ITS-RFLP marker systems in accessing genetic variation of Pyrenophora graminea. Genetics and Molecular Biology, 33 (2): $328-332$.

\footnotetext{
المستخلص العربى

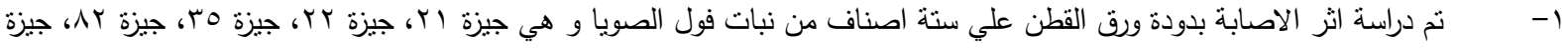

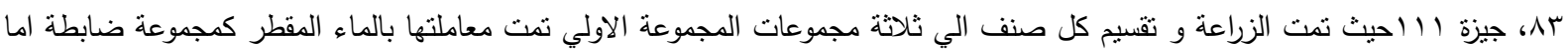

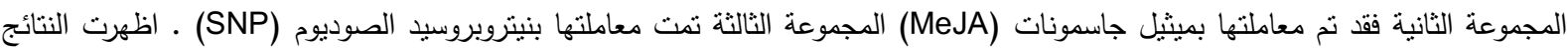
اختلافا واضحا في مقاومة الاصناف المختلفة للاجهاد الحبوي للاصابة بدودة ورق القطن حيث سجلت الاصناف جيزة r ب و جيزة r ب حساسية

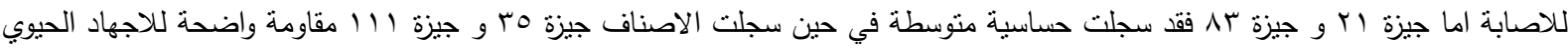

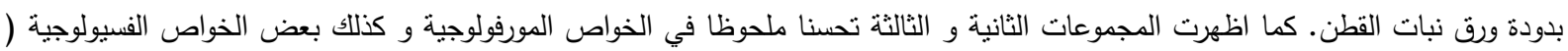

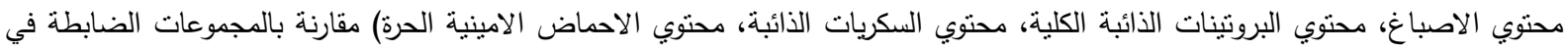

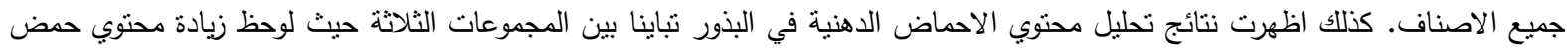

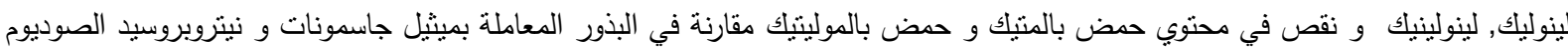

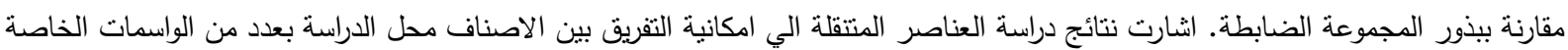

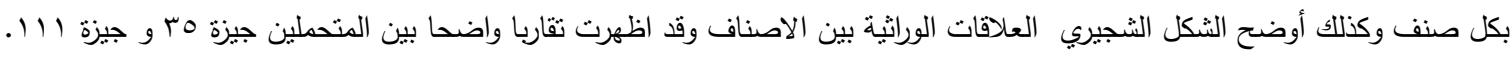
مفتاح الكلمات: فول الصـويا ، الاجهاد الحيوي ، ميثنيل جاسـمونات، بنيتروبروسـيد الصـوديوم، مضـادات الاكسـدة، الدهون المؤكسـدة، التانينات، الفلافونات و الفينولات.
} 